$\begin{array}{ll} & \text { Etnográfica } \\ \text { etnográfica } & \text { Revista do Centro em Rede de Investigação em }\end{array}$

Antropologia

vol. $13(2) \mid 2009$

Vol. $13(2)$

\title{
Scale and ethnicity in Southeast Poland: tourism in the European periphery
}

Escala e etnicidade no Sudeste da Polónia: turismo na periferia europeia

\section{Juraj Buzalka}

\section{(2) OpenEdition}

\section{Journals}

Electronic version

URL: https://journals.openedition.org/etnografica/1148

DOI: 10.4000/etnografica. 1148

ISSN: 2182-2891

\section{Publisher}

Centro em Rede de Investigação em Antropologia

\section{Printed version}

Date of publication: 1 November 2009

Number of pages: 373-393

ISSN: 0873-6561

\section{Electronic reference}

Juraj Buzalka, "Scale and ethnicity in Southeast Poland: tourism in the European periphery",

Etnográfica [Online], vol. 13 (2) | 2009, Online since 16 May 2012, connection on 12 February 2022

URL: http://journals.openedition.org/etnografica/1148; DOI: https://doi.org/10.4000/etnografica. 1148

\section{(c) (7) (8)}

Etnográfica is licensed under a Creative Commons Attribution-NonCommercial 4.0 International License. 


\title{
Scale and ethnicity in Southeast Poland: tourism in the European periphery ${ }^{1}$
}

\author{
Juraj Buzalka
}

This paper discusses the staging of Ukrainian ethnicity during the celebrations of Kupaly Night, an annual community ritual in Southeast Poland. The argument embarks from an analysis of changing nation state policies in Poland after state socialism and emphasises the growing influence of European Union (EU) policies on the public representation of ethnicity. These policies have moved ethnicity from the level of everyday practice, but also from an arena of political tensions, into an institutionalised and policy dominated form of identification. In the region of Przemyśl, where the events under scrutiny take place, tourism is another key factor facilitating the establishment of market forces in projects of heritage preservation, multiculturalism and the promotion of ethnic particularities. My analysis of how these factors have impeded on the region shows the emergence of a multicultural development project that does not have a unifying but an ambivalent effect. The paper investigates the way in which the Ukrainian minority in Przemyśl is subject to wider processes of re-scaling ethnic policies from the national to both the European and the regional level and is in this process turned into a commodifiable group valued by the EU, the state, tourists and locals for its distinctive culture. I thus demonstrate the ambivalent relationship between ritual practice, public representations of authenticity, ethno-tourism and social change influenced by EU policies and discourses.

KEYWORDS: ethnicity, European periphery, scale, Southeast Poland, tourism.

... there was nothing authentic about a farmhouse loaf when we all lived in farmhouses. (Pratt 2007: 297)

I An earlier version of this paper was presented at the conference "Thinking through tourism" of the Association of Anthropologists of the UK and Commonwealth, held at London Metropolitan University from 10 to 13 April 2007. I would like to thank the "Large scale tourism in small scale societies" panel conveners Carsten Wergin and Patrick Neveling for inviting me to this panel and for giving helpful comments on this paper. I am also thankful for comments to an anonymous reviewer of Etnográfica. The final version of the paper was prepared while I was Andrew W. Mellon Visiting Fellow at the Institute for Human Sciences in Vienna, Austria, and Visiting Fellow at the Aleksanteri Institute, University of Helsinki, Finnland. 
PEOPLE IN PRZEMYŚL, A CITY IN SOUTHEAST POLAND, SEE THEMSELVES as different mostly according to nationality and religious rite. ${ }^{2}$ In recent years the city's multi-ethnic composition has become an increasing means to market the region as a tourist destination as well as to attract funding from the European Union. Ethnic cleansings during and after World War II followed by state-socialist Poland's policies to further nationalise the country have had a significant effect on the demographic composition all over Southeast Poland. Today, the majority of Przemyśl's seventy thousand inhabitants holds Polish citizenship and identifies with Polish Roman Catholicism. Most of the traces of the once large Jewish community were eradicated from the region during the Nazi Holocaust and the only ethnic minority left in the city is that of two thousand Ukrainians following the East Christian rite in Greek Catholic and Orthodox Churches. ${ }^{3}$

In line with state-socialist policies, Ukrainian ethnicity was nearly invisible in public and instead remained limited to the spheres of the family and church. Greek Catholicism, the main memory expression and repository of Ukrainian ethnicity, had to operate under the umbrella of the Polish Roman Catholic Church. Only in 1991 did the Greek Catholic Church regain full independence. In the very same year Przemyśl became infamous across Poland and beyond when ethno-religious tensions erupted on a scale unknown in socialist times (see Hann 1998a). As the course of events would show, these anti-Ukrainian demonstrations, derogatory graffiti on walls, and anti-Ukrainian sermons in Polish Roman Catholic churches were triggered by the visit of the Polish Pope John Paul II to the region. But while the agenda for the Pope's visit was of central concern to the Polish majority of Przemyśl, the Pope's arrival and the media coverage of his journey to the region also helped to solve at least some of the public expressions of this ethno-religious conflict.

Months before the visit, in early April 1991, a group of Polish nationalists occupied Carmelite church, one of Przemyśl's main churches and a major landmark of the city. The squatters' aim was to prevent one of the main items on the Pope's agenda from being fulfilled. This was, as a gesture of reconciliation, to return authority over the church to the Greek Catholics, to whom it had belonged from 1784 to 1946. In April and May 1991, some thirty men lived in the church and its adjacent monastery. They were supported by a group of devout elderly women who demonstrated in front of the Roman Catholic bishop's palace. Every day, they showed up holding banners with slogans such

2 I undertook fieldwork in Przemyśl and Southeast Poland between the summers of 2003 and 2004 and have been re-visiting this place every summer since then. The results of my research were published as Nation and Religion: The Politics of Commemoration in South-East Poland (Buzalka 2007).

3 For an example of the responsibilities the locals had in actions against Jews during World War II in Northeast Poland, see Gross (2001). 
as: "We will not give up the Polish Church". And every day these women made a five hundred meter "pilgrimage" from the bishop's palace to the Carmelite church. Although the bishop of Przemyśl announced a censure over the church the squatters refused to leave. High officials from the Catholic Church decided to put significant pressure on the squatters only a few days before the arrival of the Pope. On June $2^{\text {nd }}$ the defenders finally withdrew. But the influence of nationalist circles was strong enough to make the Pope alter the original plan. Instead of returning the Carmelite church to the Greek Catholics, he decided to give them the Jesuit church, a place where they had held their services semiofficially since the late 1950s.

Following these events, both Polish but also rising Ukrainian ethno-nationalist movements continued to operate in the region and some later events also received nationwide attention. Only towards the end of the 1990s were the most ardent nationalist voices silenced and more than ten years after the events described above, in September 2003, the first Galician Multicultural Festival (Wielokulturowy Festiwal Galicja) was organised in Przemyśl. A mission statement was advertised on placards throughout the city claiming that the festival was "(...) a sign of nostalgia for the past, for the people who made everyday culture, for the nations who inhabited this land for centuries". In one of the festival leaflets, the organisers declared:

Our aim is to forge cultural links at the same time as Europe is uniting. $[\ldots]$ The aim of the festival is to inspire and create a growing interest in the cultures of national minorities. [...] To enhance and to promote regional culture, to encourage an attitude of tolerance between people - these are our chief objectives, the objectives of a uniting Europe [personal archive of the author].

As I want to show in this paper, the Galician Multicultural Festival was part of a wave of fashionable celebrations, idealising the good old days before World War II in Eastern Europe. The celebrations picked up the historical name of the region, Galicia, and were staged expressions of an idea of multiculturalism that had arrived in Przemyśl only five years earlier. Since then, such promotions of multiculturalism and peaceful coexistence of ethnically diverse communities have become key catchwords in the campaign marketing Przemyśl as a tourist destination. But these changes are not always for the benefit of the local minorities' grassroots activities, as the account of the Kupaly Night ritual central to this paper proves.

On the following pages I engage in detail with the problems arising out of efforts to implement and develop tourism and multiculturalism and this policy's effects on public representations of ethnicity. After introducing the theoretical framework according to which I analyse the ritual of Kupaly Night, 
I will give an overview of the historical development of tourism in the Przemyśl region. Based on a detailed comparison of two ritual celebrations held in the years 2004 and 2005 respectively, I argue that ethnic identification has been re-scaled after state socialism for two reasons. Firstly, it has been driven by the already mentioned emerging multicultural ideology of the Polish state and the EU and, secondly, it has been re-scaled by the expansion of market exchange forces into this peripheral region of Europe. Both reasons intertwine as they contribute to and depend on increased economic stratification among the local population and an unequal allocation of resources locally as well as regionally. Regional development of the tourism sector further enhances cultural stereotypes based on ethnic belonging.

\section{ETHNICITY, SCALE AND TOURISM ON THE POLISH-UKRAINIAN FRONTIER}

Besides the significant role policies and discourses resulting from Poland's integration into the EU have played in the region, it is particularly an emerging tourism sector that by now shapes notions of "ethnicity" and "authenticity". From an analytical perspective, it is worth looking first at the processes of re-scaling these concepts, formerly confined to the nation-state and recently subjected to the wider European policies. A second and related process of re-scaling has strengthened the impact of regionally-defined power where the notions of "ethnicity" and "authenticity" have been adjusted in order to better suit tourist expectations. As in other parts of Europe, this does not mean that there is now a lack of correspondence with the policies of the Polish state but instead, that these state policies have been blended in with the multicultural ideologies promoted by the European Union. Celebrations of diversity, famously outlined in the mottos of the European Union, "united in diversity" and "subsidiarity" (Shore 2000), serve as a source of legitimacy for elites operating from within the Polish state, municipal bureaucracy and via NonGovernmental Organizations (NGOs). An important quality of this legitimacy is that elites are now provided with a means to intervene in representations of ethnic diversity leading for example to the re-scaling of the Kupaly Night ritual analysed later in the paper.

Both the tourism industry and the new elite discourses are shaped by and rely on the fact that a major part of Eastern Europe ceased to be agrarian quite recently through state-socialist modernisation. Other than those regions of Europe industrialised in the $19^{\text {th }}$ century, many parts of Eastern Europe (including Southeast Poland) show a peculiar interdependence between notions of ethnicity and their belated development (Brubaker 1996; Brubaker et al. 2006). Despite attempts to implement modernisation policies, state socialism reproduced many elements of rural life such as the role of kinship, religion, and rural identities. These elements have a crucial influence on post-socialist 
development and continue to shape the region's transformation following integration into the EU in 2004. Thus, in many parts of Eastern Europe ethnicity is much more easily conceptualised and essentialised by locals than any other collective identity (Kanovský 2007). This has crucially shaped regional development of the tourism sector as tourism development initiatives have influenced and had an impact on notions of ethnicity and authenticity in peripheral areas.

Looking at the place of authenticity in tourism research focusing on identity and its expression (see Stronza 2001), ethnicity in Central and Eastern Europe thus might more easily substitute and/or reinforce other elements of culture the locals want to show and share with tourists as "authentic". Because in this region both locals and tourists share an obsession with ethnicity, ethnicity plays a significant role in the production, distribution and consumption of culture. As in other parts of the world, people in Southeast Poland "decide to consume or not solely with regard to cultural meaning. As a group, their decisions form a structure of wants that recreate broader cultural regularities" (Carrier and Heyman 1997: 360). This observation on the interrelatedness of consumption patterns and the self-reflection of groups on their identity is in line with recent criticism of concepts on ethnicity within social anthropology (and particularly within contemporary migration scholarship). These critics have emphasised the importance of perceiving ethnicity as a mode of social and economic incorporation that is related to the relative position of cities and regions in the global economy. The latter position, understood as "city-scale" for example, incorporates a number of non-ethnic pathways, of which multiculturalism is one, along which small and peripheral cities operate as they try to position themselves on the world map in order to attract investment and particularly the tourism industry (Glick Schiller, Caglar and Guldbrandsen 2006). Ethnicity, as part of tourism development, should thus not be treated as the sole quality of individuals identifying with a group through symbolic means. Instead, like other modes of incorporation, ethnicity is an experience and perspective on the world constantly re-scaled through the production, distribution and consumption of culture shaped by the historically-changing position of a particular region in the global economy (cf. Neveling and Wergin 2009, this volume). Due to the post-peasant basis of East European politics (Buzalka 2007, 2008) processes of Europeanization (Borneman and Fowler 1997) - in particular those embracing neo-liberal economic reforms, politics of multiculturalism and regional development, such as support of tourism and agriculture - have thus made the region particularly suitable for the widespread phenomenon of "ethnic and cultural tourism" (Smith 1978: 2).

Justus Uitermark explains the relationship between social relations and space through the changing scalar organization of society in an emerging neoliberal world order. This new world order has not only had an impact on the 
Keynesian mode of regulation in Western countries (Uitermark 2002) but has as well significantly altered state-citizen relations and economic structures in post-socialist Poland (cf. Dunn 2004). The dominant mode of nation-based regulation in socialist times was re-scaled after the fall of socialism and neoliberal development empowered regions as well as supranational structures like the EU who from then on became important actors in the distribution of resources.

The post-peasant basis and the importance of ethnicity in Eastern Europe have made Southeast Poland particularly suitable for "ethnic" tourism. ${ }^{4}$ As Neveling and Wergin argue (2009, this volume), scale as an analytical tool opens up a view on exactly this twofold process that produces political and economic inequality as well as cultural stereotypes. Based on the example of ritual tourism in Przemyśl, I show that even in this obviously peripheral region, an ideology of globalisation predominates according to which "no units or scales count for much except the globe" (Tsing 2000: 328). One way to reveal these hidden dimensions and thus to analyse the importance of scale is to first pay attention to ideologies of scale, that is, "cultural claims about locality, regionality, and globality". Secondly, it is necessary to focus on "projects of scale-making" which despite common claims to a fragmented global reality often come as "coherent bundles of ideas and practices as realized in particular times and places" (Tsing 2000: 347). This paper, therefore, conceptualizes the "global situation" in relation to ethnicity and highlights the twofold process taking place in Southeast Poland: ethnicity has been re-scaled as the result of Europeanization and neoliberal globalisation but at the same time the regional practices of ethnic belonging contain and refer to the people's own projects of scale-making.

As Annegret Haase (2002) has mentioned, Southeast Poland was and remains one of the least developed areas of the country. Rural regions, especially, suffered from a lack of state investment during the communist years. This lack of investment continued in the first post-socialist decade and contributed to a significant outward migration of the region's work force. For those who stayed, seasonal work and semi-formal labour relations often based on kinship and friendship ties were the predominant opportunities of employment. Although the number of people working in agriculture has fallen since 1989, in 2006 such work still represented about one-fourth of the total employment in Poland. ${ }^{5}$ The number of people working in agriculture was 15 per cent higher in Southeast Poland than in the country as a whole, and the majority of farms

4 For similar developments in other parts of the world, see Guneratne (2001), Van den Berghe (1994), Hiwasaki (2000).

5 Source:<http://www.stat.gov.pl/opracowania_zbiorcze/duzy_rocznik_stat/2006/drs2006-dane_o_ wojewodztwach.pdf>, pp. 66-67, accessed January 2007. 
were small - less than ten hectares - and privately owned (Haase 2002: 54). This rural setting I call post-peasant is perceived to be particularly authentic among many inhabitants of the region as well as visitors to the region. ${ }^{6}$ In 2002, 59.5 per cent of the population of Podkarpackie County was living in villages. The comparable figure for all of Poland was 38.4 per cent. ${ }^{7}$ Przemyśl remains the second largest city of the region. In May 2004, its unemployment rate was at 21.5 per cent. Outside the city boundaries it was at 24.9 per cent. $^{8}$ Both figures were not only above the national average but also the average of 20.6 per cent for the county. ${ }^{9}$ The largest formal employers were the state and the municipality, although the Church also formed an important part of the local economy.

The proximity of the Ukrainian border and the city of L'viv, with almost one million inhabitants, offers opportunities for the population to work their way out of this peripheral position. Expectations are that EU funding going into tourism, infrastructure and agriculture as well as commerce with Ukraine will save the region from further impoverishment. Such expectations were especially strong among local elites and Polish development agencies before the global economic crisis of 2008 and 2009 hit the Ukrainian economy. Presently hopes are high that financial support for Podkarpackie County from the European Union will reach 1.6 billion euros in five years time. ${ }^{10}$

But in the 1990s and early 2000s, westward labour migration remained high and petty trade tourism across the Polish border flourished. In 1996, more than 1.5 million Ukrainians crossed the border in Medyka, the closest frontier post to Przemyśl, for both transit and shopping (Haase 2002: 117). In 2004, this petty trade tourism was already on the decline and Poland's integration into the Schengen Zone in 2008 has affected this trade further. Nevertheless, petty trade tourism still brings profit to people on both sides of the border. Perhaps the most visible everyday presence of Ukrainians in Przemyśl is at the bazaar, in the mid-1990s the second largest in Poland and only topped by Stadion Dziesięciolecia in Warsaw. Back then, everyday trust prevailed over ethnic differences at the bazaar in Przemyśl (Hann 1998b).

At the same time, nationalist politics and international outward migration strengthened the Polish state's and Poland-wide NGOs' interests to attract funding from EU development programs. "Multi-ethnicity" has become one of the catchwords within political programs promoting regional development. This has triggered the above discussed processes of re-scaling that can be observed in a move from daily patterns of ethnic coexistence and everyday culture towards

6 On the importance of villages in the nation construction in Moldova, see Cash (2007).

7 Source: <http://www.stat.gov.pl/demografia/index.html>, accessed December 2005.

8 Žycie Podkarpackie, 12 May 2004.

9 Žycie Podkarpackie, 14 April 2004.

10 See <http://miasta.gazeta.pl/rzeszow/2029020,34962,3205662.html>, accessed March 2006. 
celebrations of ethnic diversity and the marketisation of a multicultural past. Although the latter project, mainly enhanced by municipal, national and European institutions, could supposedly be perceived as a more integrative way of incorporating diverse ethnic groups, this project actually contributes to strictly drawn boundaries between ethnic groups. The close examination of two consecutive versions of an annual ritual called Kupaly Night (Nitsh Ivana Kupaly), held in 2004 and 2005, paves the way for a better understanding of these changes in the re-scaling of ethnicity.

\section{KUPALY NIGHT: A COMMUNITY RITUAL}

Kupaly Night is the adaptation of an ancient, pagan summer-solstice celebration, associated with St. John's Day. It first became an ethno-revivalist ritual in Southeast Poland at the beginning of the $20^{\text {th }}$ century, when Kupaly ceremonies were organised in Przemyśl by the increasingly active Ukrainian intelligentsia. These were held annually in the region's East Christian villages until the end of World War II and over time came to be considered Ukrainian national festivals. The ritual took place at sundown and involved people singing folk songs and dancing folk dances around bonfires. In a grand finale, participants bathed in a creek as the term Kupaly is derived from the Slavic word for "bathing".

The twin of Kupaly Night is an older, bigger, and better-known event, the Lemko bonfire (Lemkivska vatra). This ritual's more recent history corroborates the observation that popular ethnic festivities are increasingly commoditised in Poland and across Eastern Europe. The annual Lemko festival, held since the 1980s at the end of July in the village of Zdynia in the Polish Carpathians, is today financed by the Polish state and attracts sponsorship from big companies. At the same time, as such celebrations are increasingly valued by the few remaining groups of non-Poles, "Polish" traditions, folklore, and rustic images of the countryside are also undergoing a significant revival. While events like Kupaly Night and the Lemko bonfire are often perceived as strengthening multiculturalism in Poland, they have also become excellent commodities for the tourism industry. This is particularly evident in the following close examination in the re-scaling of Kupaly Night taking place in 2004 and 2005.

Posada Rybotycka is a village situated some thirty kilometres southwest of Przemyśl in the Wiar Valley amid the beautiful Przemyśl Hills. Because of post-war international agreements and ethnic cleansings, most of the Ukrainian inhabitants of the valley were moved to the area around Tarnopil in contemporary Ukraine. Those remaining were forced to leave during Action Vistula, a project of state-led ethnic cleansing carried out in 1947 when the Polish state re-settled tens of thousands of Ukrainians to northern and western parts of the country acquired from Germany. As Poland became one of the 
most ethnically homogenous countries in Europe after World War II, Ukrainian public life was suppressed. Soon after the collapse of state socialism the presence of Ukrainians in public life became increasingly evident and this attracted propaganda campaigns by Polish nationalists like the one described in the introduction to this paper (see also Buzalka 2007).

Posada is now greatly diminished from its pre-war size. The wooden houses of Ukrainians were razed during the socialist years and some of them replaced by dispersed cooperative dwellings. Only the ancient tserkva (the sanctuary of Eastern rite Churches), the parish house, and the cemetery reveal the location of the old Greek Catholic village. In the 1950s the sparsely populated hills, with their ruined villages, their tserkvy and the new settlers who were indifferent to the land became known as the Polish "wild east". But today, signs of increased tourism are everywhere. The remains of tserkvy and the cemeteries are preserved and information plaques are installed next to them as the region has been discovered for its apparently authentic tradition and wild nature. A trainee working for an EU project on cultural heritage preservation stated optimistically: "The Podkarpacie region opted for tourism and history, and we will make a lot of money out of it." This is to be achieved not only through preservation of the natural environment and support of agriculture but also through the rich multicultural heritage of the region. Within this process, the Kupaly revivalist ritual presents an example for the changing importance of Ukrainian public representation in the region, which the Polish state, NGOs and local elites are jointly trying to integrate into a multicultural project. Such forms of growing display and promotion of culture as grounded in a particularly "natural" territory have been observed in other parts of Europe, for example in the southwest French wine region (Ulin 1995), in Tuscany (Pratt 2007), or in Cornwall (Hale 2001).

Since the 1980s, Posada Rybotycka and the surrounding area have increasingly become a tourist destination. Walking trails crisscross the area, which is also popular among cyclists because traffic is light on the barely repaired roads. In this period of a prospering tourism sector, two Przemyśl Ukrainians bought an old cooperative building, turned it into a bar and began to offer accommodation to tourists. Another local entrepreneur rented the former Greek Catholic presbytery and refurbished the building into a tourist hostel. These people, active members of the Przemyśl Ukrainian minority, have been involved in reviving the village ritual Kupaly Night. Since 2000, they have organized this annual event on the weekend before or after St. John's (Ivan's) name day (the day of St. John the Baptist, according to the Greek Catholic calendar) together with young Ukrainians from Przemyśl and the Przemyśl branch of the Association of Ukrainians. This ritual has changed the ethnic identification of Ukrainians in the region and would not have been possible without the help of the state, exercised via public media and funds providing direct sponsorship for 
minority cultures. Furthermore, development strategies aiming to attract tourists to the peripheral region have strengthened but also altered these annual ritual practices. As the following section will show, this development of marketised multiculturalism reflects the way in which ethnicity is re-scaled from an everyday form of social practice, observable among the neighbours and at the bazaar, into a politically dominant group identification that is supposed to attract tourism and investment into Southeast Poland.

\section{KUPALY NIGHT 2004}

The weekend before the Kupaly Night of 2004, on the $4^{\text {th }}$ of July, young men from Przemyśl went to Posada to collect wood for bonfires, dammed the creek with stones to create a small, temporary pond, and cut grass in a nearby field where people would gather later. They prepared a campsite and set up a mobile bistro. Some weeks before, organizational meetings had been held at the Przemyśl Ukrainian National House to settle financial and logistical matters. Leaflets had been printed and distributed, and the office of the Greek Catholic bishopric had been asked to send a priest to conduct a Sunday service. To support more mundane activities, two music bands had been hired.

The following Friday, some of the organizers returned to Posada to make final preparations and on Saturday morning the participants began arriving. A stage and amplifiers were set up for the bands and other entertainers. Near the creek, benches arranged under a large tent awaited the guests, and next to it, a caravan offered fast food and beer. The bar in the former cooperative building was opened, serving beer, soft drinks, and ice-cream. Teenage girls from the Ukrainian school in Przemyśl, who later became the main actors in the night time ritual, collected wildflowers and practiced singing and dancing for their performance. Young men cut additional wood, drank, and sang folksongs nearby. The ritual, the fifth since its resurrection in 2000, was a communal activity of the regional Ukrainian minority association and conveyed the atmosphere of a village festival. There were no hints at how this was going to change in the following years. In retrospect, however, some signs of change for how the ritual was to become one of the local brands for developing heritage tourism in the region can be identified. The following description is built on these leads, in order to prepare the comparison with the event in 2005.

Central to these signs of change was a group of men with TV equipment that walked around and chatted. They had come from Kraków regional television to film the event for the TV series "Ethnic Climates" (Etniczne klimaty), a monthly program for and about the national minorities and ethnic groups in Poland. Among the journalists was the dark-skinned moderator of the program, Brian Scott. He described himself as "the only black Polish journalist" 
and continued, "I have done a lot for the coloured people in this country. I am their guy in the Polish media." 11

Scott had come to Poland twenty years earlier. He originated from one of the African countries friendly to socialism, had studied journalism in Kraków, and married a Polish woman. As the reporter of the magazine-format "Ethnic Climates" he worked together with the initiator of the series, the experienced journalist Waldek Janda, whom he characterized as, "an engine of ethnic programs in the public media and of programs about minority and ethnic groups in Poland". These programs were transmitted throughout Poland as well as regionally. They were about "Slovaks, Kashubs, Bielorusyns, and other minorities and ethnic groups". As Scott stressed, he and his colleagues worked to help minorities to keep...

[...] their identities, their culture, their religion, cultural events, sport, etc. [We are interested in] young people, old people, places of tradition, maybe their past. [We focus on] things like monuments, cemeteries, [and] schools. [We want to know] in what ways the national minorities in Poland are keeping their identity. Who is helping them? Is the Polish state doing enough for them? And the local authorities, municipalities... what do they do for them? [author's personal communication, 04/07/2004]

The journalists saw their role at Kupaly Night in an "ethnographic" way, as Brian Scott put it. It was the Ukrainian minority they were going to "do a lot for". Not only TV, almost every regional radio station nowadays broadcasts a program that could be characterised as "ethnic". After our brief discussion, the journalists got to work. For the rest of the day, everything that happened in connection with the Kupaly celebration was adjusted according to their wishes. One person commented: "Kupaly is changing into a media event. The photographers and TV teams allow no concentration on the internal aspects of the festival; they prefer the external, visual side and the fact that in a few moments all of Poland will see us."

The role of the journalists in the Poland's ethno-revivalism goes hand in hand with development programs that present culture as locked within nations and based on marketable ethnicity and multiculturalism. Through such media coverage, a Poland-wide audience is learning about the Ukrainian minority in the country's Southeast. This contributes to the re-scaling of ethnicity by strengthening cultural stereotypes and promoting the region to potential tourists, mainly inhabitants of large Polish cities.

11 All quotes in the following description of the ritual are based on personal communications of the author and have been translated from Polish to English by him. 
In addition to the marketing of ethnic stereotypes, media attention was also given to displays of Ukrainian cultural practices staged around the ritual and portrayed as rooted in the region. One of these practices emphasised the value of homemade peasant food and strengthened the perception of food production as a craft process, opposed to mass production, thus enforcing an image of authenticity as "not a survival from some prelapsarian world of peasants and artisans, but precisely a shadow cast by an economy organized around exchange value" (Pratt 2007: 295). This presentation of "authentic" Ukrainian food production techniques for Polish media audiences started with a buttermaking competition. A woman of around forty gave a general introduction to the Ukrainian national cuisine. One of her female assistants invited the male spectators to help with the cooking and two of them agreed to join in preparing the Ukrainian soup borshch. A microphone and camera followed the presenter as she cooked and commented on how to prepare the dish. As in the case of food movements in Italy and France, the ethnic revivalism of Southeast Poland incorporates the recreational habits of middle classes and intelligentsia (Pratt 2007: 295). The peasant past of the Ukrainian minority is turned into an image of authenticity, re-scaled by market forces, that is in line with the demands of the EU and nation-state policies on cultural heritage and preservation.

Throughout the day of the Kupaly Night Ritual in 2004, folk music was being played, either from a tape recorder or by live bands. With the evening approaching, the crowd grew larger as both Ukrainians and Poles from Przemyśl and other cities arrived by car, bus, or bicycle - some of them even from other parts of the country. After sunset, everything was ready for the Kupaly ritual, and several hundred people awaited the performance. The signal came when the young men in the ritual lit bonfires. Once the fires were burning, the young women performers mentioned earlier, now standing on the opposite side of the creek, began singing songs about love and nature. They wore folk dresses and had garlands of wildflowers on their heads and chests. Camera flashes lit up the valley as one girl appeared from the dark and sang, answered by the others. Holding hands, they made a queue and moved closer to the water, leaving a space for the girl coming out of the dark. She walked to the middle of the circle the girls made after reaching the creek, and all the girls danced slowly into the water. The boys approached the girls' circle, broke it apart, and began to chase individual girls. Whenever a boy caught a girl, he took her hand and they stepped back into the dark.

The whole ritual lasted for about 45 minutes. Near the end, the girls threw their garlands into the water for the boys were to collect them out of the creek. Afterwards, the journalists ran to their offices to prepare the news and most people went home to Przemyśl. Those who stayed continued singing and drinking. The men moved to songs about shooting, heroic military life, and tragic love, going on until sunrise. On the following day, music sounded 
from the veranda of the parish house where the journalists from Kraków shot additional footage for their documentary. Music also came from the field near the Wiar. People walked back and forth between the two places. On stage, a "cultural program" started with performances by music bands.

Many of my friends characterized these events as "the end of romantic times". They referred to the increased commercialization and "mediatisation". People wanted to show their rich Ukrainian culture to a Polish audience and welcomed journalists to the festival, but many felt offended by the aggressive form of media coverage and public display of what they considered their ritual. They noted a loss of authenticity of the once intimate community celebration. One participant, aged thirty-six, commented:

I take part in Kupaly every year. I like to go there. I liked it most at the beginning, when everything was fresh; the emotions were authentic... I liked that it was not an artificial resurrection of folklore but an authentic experience and a kind of fun with that folklore... After a couple of years, however, I grew to like the event less - the routine, schematic activities, the tape players as the basis for the girls' singing, and so on. Also, a lot of beer showed up... But I still go there. It is one of the few [Ukrainian] events also attended by Poles.

One of my neighbours in Przemyśl also acknowledged these changes but referred to them from a longer historical perspective. He remembered Kupaly Night as the "feast of love, a kind of combination of pagan-Christian tradition... when youths jumped over the fire". From the perspective of many young Ukrainians, Poles only attend the ritual because it is "an attraction". Ola, aged twenty-three, remarked that Kupaly Night was "an artificial party now; everybody is filming it just because it looks exotic". Many other people criticised that each year the event had become more commercialized particularly because now food, drinks, and folk artefacts were sold and the event was advertised in the media. As described on the following pages, forces of the market go along and interfere with projects of heritage preservation, multiculturalism and the promotion of tourism.

\section{KUPALY NIGHT 2005: RE-SCALING THE RITUAL}

The ritual in Posada was perceived by the participants with ambivalence in 2004. ${ }^{12}$ Despite of limited signs of commercialization, it was a local event

12 This self-perception process among the native Ukrainians towards tourism gives rise to a process similar to the one Alexis Bunten (2008) described as "developing commodified persona". As the native tourism workers in Alaska participating in heritage industry, so the local Ukrainians consciously protect some aspects of their culture from commodification. 
organized predominantly by the voluntary work contribution of local Ukrainians. On July $2^{\text {nd }} 2005$, however, Kupaly Night was organized near Przemyśl's city centre, next to the city's best-known hotel and near camping facilities and a sports stadium. In the afternoon, Przemyśl's new "Švejk's tourist path" was officially opened as part of the open-air re-enactment of "Švejk's Manoeuvres", intended to serve as a reminder of old Austrian times and staged to become a magnet for tourists. ${ }^{13}$

The Kupaly ritual, performed this time by a Ukrainian folklore ensemble and not by the locals of Ukrainian descent, took place in the evening around a bonfire. A covered stage with lights and other technical equipment was erected, surrounded by kiosks offering folk crafts, folk dishes, and books. Further in the background stood two fast-food tents. The city's hotel sold beer and hosted an icon-painting workshop for children.

In addition to state subsidies, the organizers had received organizational and financial support from Przemyśl city council. In contrast to the 1990s when the city council was strongly anti-Ukrainian, changes in local politics had brought about a new attitude towards the city's ethnic minority and the multi-ethnic past of the region. The mayor himself opened the festival with a speech highlighting the multi-ethnic and multi-religious heritage of the region. While Ukrainian was also used, the main language of the event was now Polish. Several thousand people were present at the climax of the ritual. The crowd was so large that only a few dozen people were actually able to observe the performance around the bonfire and in the river.

Before the night-time ritual started, a choir performed artistically arranged Ukrainian folksongs on stage. I asked one friend, an immigrant from Russia who had lived in the city for several years, why he thought the Kupaly celebration had been moved from Posada to Przemyśl. He replied:

It is the fashion today; Ukraine is in the headlines [...] The city council gave money for it [whereas] before they did not. If there had been no Orange Revolution [the change of regime in Ukraine in 2004-2005], they [local Ukrainians] would have been sitting in Posada all the time. There they were amongst their own; nobody intervened in what they did. Here, you know that they [local Ukrainians] want to show up [...] Everything is about politics. ${ }^{14}$

13 The open-air performance "Švejk's Manoeuvres" (Manewry Szwejkowskie) is an enactment of parts of the story "The Fortunes of the Good Soldier Švejk in the World War", written by the Czech novelist Jaroslav Hašek. Dealing with a "good soldier" in the Austrian Army, the story takes place partly in Galicia.

14 When the independent Ukrainian state was established in 1991, the Ukrainians in Poland were more and more perceived as diaspora Ukrainians. This nationalization of the minority in inter-state relations represents another way of how the minority ethnicity became prominent in [continues] 
Later I met two young women from the city of Sanok, seventy kilometres west of Przemyśl. They wore folk dresses and waited to go onstage. They criticized the performance given by the folklore ensemble from the Przemyśl Ukrainian school as artificial, lacking authenticity because it included folk music from a synthesizer, percussion from loudspeakers, and well-prepared choreography. The two women said that they instead would sing proper Carpathian songs in an authentic manner, without electronic instruments.

Compared to the situation in Posada in 2004, the Kupaly Night had become an important, officially recognized multi-ethnic festival. Whereas one year before, a local TV-station had been present and documented the ritual in order "to do a lot" for the Ukrainian minority, the display of ethnicity was now of different importance. The scale of the ritual had changed not only in terms of its location, financial subsidies and revenues but also in terms of participation. More Poles attended the event than in the year before. My Ukrainian friends appreciated this change, arguing that it helped to strengthen mutual sympathies between the two nations. Nevertheless, some of my friends also remembered the intimate atmosphere of the Kupaly Night in previous years. In Posada they used to bring their own sausages and drink their own beer and vodka. Here, food and drinks were sold and the event seemed impersonal.

Meanwhile in Posada Rybotycka, late that July $2^{\text {nd }} 2005$ the atmosphere was depressed. The grass had been cut in only a small area near the road. About a mere twenty young people gathered around a fast-food caravan selling beer and sausages. The old wooden stage was half-covered by a tent, music sounded from a tape-recorder. The night had turned into a drinking session. No ritual performance took place. On Sunday morning, people shared food and the remaining drinks. During the day they bathed in the creek. The boys continued grilling, some played football, others dragged the girls into the water "to remind them of Kupaly Night" as they said. The people called their event the "competing Kupaly". Around noon that Sunday, two friends from Przemyśl arrived by bus and joined the group. They brought the news that an excellent party had been held in Przemyśl, but they also expressed the view that they had missed the atmosphere of the old Kupaly in Posada.

Andryi was the only one of the original Kupaly Night organizers who had decided to hold the event in Posada that year. He felt that his friends had betrayed him when they agreed to hold the ritual in Przemyśl. He still hoped that in the following year he would be able to bring Kupaly Night back to Posada:

They [the new leadership of the Ukrainian Association] were saying that people just drink here. But it is a pagan festival - people have to drink! It 
turned out so well last year - two thousand people attended. The old inhabitants of Posada from Ukraine were planning to come this year, but they could not [because of the change of venue].

Andryi remembered that in 2000 the Kupaly celebration had been a voluntary event, and no one had asked for a salary. Today, professional organizers and ensembles were hired. In Posada, one of his friends from a nearby village had come to cut the grass with a tractor and Andryi had bought food and beer to sell at his hostel in the former parish house at almost no mark-up. He had lost not only his illusion about the intimacy of Kupaly Night, he remarked, but also some modest earnings and publicity for his hostel. With the end of the ritual also the days of petty tourism business in Posada was over. One of the people who had turned the former cooperative dwelling into a hostel planned to sell out his share. The bar had already been closed. I heard some gossip that Ukrainians with economic interests had caused the Kupaly location to be changed, but Andryi did not want to talk about it.

\section{COMPETING CELEBRATIONS OF ETHNICITY}

The Kupaly Night ritual in Posada had been a community activity. Although a development turning the ritual into a regional event was already becoming visible in 2004, the incorporation of business and state sponsorship as well as the political importance for the region had remained marginal. In the following year, a one-sided competition of projects of scale-making (cf. Simoni 2009, this volume) took place and the ritual was held in Przemyśl. Decisive for the outcome of this competition and the ensuing re-scaling of ethnicity had been local, national and EU interest in the promotion of a multicultural ideology. Due to the impact of this ideological shift, the actual Kupaly Night ritual had changed in scale and political importance as it moved from the village to the city. Only with this extension of the ritual to encompass a wider audience, struggles about authenticity and the ensuing right of public representation emerged. In relation to the hostilities against Ukrainians and their public presence in Przemyśl that had occurred in the 1990s an important change can be observed, however. In 2005, struggles were of a much less antagonistic kind and virtually all my Ukrainian friends appreciated the presence of numerous Poles and the city council's interest in co-organising the festivities. Unlike Andryi and a few of his compatriots, the vast majority of Ukrainians I talked to actually wanted to keep the event in Przemyśl in order to present their "rich Ukrainian tradition" to a wider Polish audience. They believed that more tourists would attend the festival in Przemyśl and that more politicians, who decide on subsidies for national minorities, would notice it there. 
It seems certain that in the future, this re-scaling of the ritual in Przemyśl will continue. The costs of advertising and subsidising the event will grow. The city will contribute to the costs, as will the central office of the state-sponsored Association of Ukrainians in Poland, which has included Kupaly Night in its official calendar of activities. Kupaly Night is no longer a spontaneous, voluntary, local ceremony but an ethno-festival organised by professionals.

Some Ukrainians, though, feel ambivalent about this kind of development. They are disturbed by the growth of ethno-businesses, the activities of the media, and the way their rustic tradition has started to attract Poles. As Jon Mitchell (2002) observed for Malta, the Kupaly ritual expresses and accommodates the dilemmas and ambiguities inherent in modernity's tendency to divide the world into "modern" and "traditional". The staging of Kupaly Night in Przemyśl indicates the consolidation of Polish-Ukrainian relations. At the same time these relations are now framed within an understanding of tolerance shaped by a multiculturalist ideology and nurtured by the growing importance of ethno-businesses and the heritage tourism industry. The commodification of the "invented" tradition of Kupaly Night in Southeast Poland offers a means to achieve greater prosperity. As the ritual discussed in this paper shows, the expression of other traditions of the Ukrainian minority is increasingly connected to the decentralisation of policy-making processes and the increased importance of regionalism and cultural politics (Boissevain 1992), which are promoted by the European Union as part of the "People's Europe" model (Shore 1993).

The re-scaling of the ethnic ritual Kupaly Night is thus best understood as a response to various socio-structural changes in post-socialist Poland. Mass tourism is a key driver of these changes, especially in peripheral regions. People in Southeast Poland have been reacting to a number of new cultural models introduced from above since 1989. Some of these changes have meant the commercialisation of cultural models already in practice, others have been more substantial like the changing Catholic liturgy after the Second Vatican Council or the growth of the electronic media sectors (Boissevain 1992: 16, 1996). The authors Glick Schiller, Caglar and Guldbrandsen (2006) have shown how hard local officials in peripheral cities have to work to attract capital. They need to market their cities by recasting their localities as centres of specific knowledge and emphasise a city's cultural specificity (2006: 616). Within this wider development of competing city scales, Southeast Poland opted for tourism as a way of preventing underdevelopment. Many officials argue that there had been no other options due to the poor infrastructure and the distance from Western markets. The elites of Przemyśl intend to build the region's (and their own) future within the EU on tourism, for which the promotion of a distinctly regional culture is particularly valuable. Whereas European integration has led to processes of re-scaling modes of regulation from the national to the regional 
and to the European level (cf. Uitermark 2002), in this case study of an emerging regional tourism economy it is the politics and expressions of ethnicity that are re-scaled as an essential component in the construction of a Europeanised modernist discourse.

Another important development in the post-socialist world is that people are increasingly enchanted with various forms of spirituality (Potrata 2004). In Southeast Poland this enchantment is manifest in the popularity of Eastern Christian images and practices. Poles and Ukrainians described their enchantment as both in continuity with as well as a return to an original, "authentic" Christianity characterised by purity and archaism. Jonathan Friedman wrote (1994: 243) that, "traditionalism is expressed in the desire for roots, the ethnification of the world, and the rise of the 'fourth world', the return to religion and stable values". In the face of rapid social change a similar emergence of traditionalism might be the driving force behind the growing political significance of ethnic festivities in post-socialist Przemyśl. Modernity is generating pressures that give rise to a new re-scaling of representations of ethnicity and culture (cf. Boissevain 1992: 15). In this process, what some perceive as traditions is becoming dispersed in a wider array of ideas and practices triggered by an increasingly fashionable multiculturalism.

In Przemyśl, ethnicity has undergone a change from everyday experience to its celebration and public display on a scale unknown in socialist and presocialist times. But elite-driven discourses and practices of ethnic re-scaling largely ignore the importance of ordinary aspects of plurality within which ethnicity plays only a secondary role - if it plays one at all. A Przemyśl district officer mentioned to me that during the nationalist tensions of the 1990s, "the Ukrainian vodka and cigarette smugglers in the bazaar had not a clue about what was going on. It was a sign [that] normal relationships [continued] trade, contacts between young people, and so on." Although he was derogatory of the petty traders and unfriendly towards local Ukrainians, he pointed out that religious-national differences played no significant role in a place where commodification and politicization of ethnicity were hardly present. A local artist who sold socks in the bazaar confirmed this view: "People started to see that every conflict with Ukrainians stopped in the bazaar." One friend of mine told me that even the Polish nationalist activists who were busy turning the public sphere into an extremely intolerant setting were making deals with Ukrainian traders at the bazaar in fluent Ukrainian language back then.

The Kupaly Night ritual incorporates and expresses a traditionalist narrative of Ukrainian ethnic roots in Southeast Poland which following changes in the ritual's location and staging are now performed for tourist audiences. These changes exemplify a move away from nationalist rituals, widespread especially in the 1990s. The common ground of this twofold process of ethnic revivalism is a narrative based on authentic tradition, spirituality, bounded 
culture, and closeness to nature. Here, changing scales of ethnicity nurtured by the EU and nation-state policies go hand in hand with the demands of a growing ethno-business, increased media coverage and the tourism sector. Similar to re-scaling processes in the Netherlands (Uitermark 2002), local elites as well as state development agencies attempt to position the city and region of Przemyśl as a "particular" tourist destination in Poland. One of the ways to make this promotion successful is to present the city as the centre of a multicultural past and present.

This multiculturalism takes the form of a romanticised blend of the good old days of the aristocratic upper classes and an idealised notion of the peasantry. But the promoters of this ethnification process, intellectuals, media employees, ethno-entrepreneurs and politicians, ignore the everyday non-ethnic side of coexistence of Poles and Ukrainians. The effects of this ignorance can be observed in the vanishing petty trade in the bazaar or in the decline of community activities involving neighbours and friends of both ethnic backgrounds. Instead, culture becomes locked within modernist perceptions of nationhood. As such, the re-scaled ethnicity of post-peasant Southeast Poland performed on Kupaly Night conceals rather than eliminates the nationalist logics behind the promotion of multiculturalism. This logic will gain in prominence under the influence of further transnational migration and proliferation of the market, not least in the form of tourism. As seen from an economic perspective, the emergence of this multicultural development project is supposed to save the region from poverty. On an everyday level, however, it does not have a unifying but an ambivalent effect.

\section{REFERENCES}

BOISSEVAIN, Jeremy (ed.), 1992, Revitalizing European Rituals. London, Routledge.

—, (ed.), 1996, Coping with Tourists: European Reactions to Mass Tourism. Oxford, Berghahn Books.

BORNEMAN, John, and Nick FOWLER, 1997, "Europeanization”, Annual Review of Anthropology, 26: 487-514.

BRUBAKER, Rogers, 1996, Nationalism Reframed: Nationhood and the National Question in the New Europe. Cambridge, Cambridge University Press.

BRUBAKER, Rogers, Margit FEISCHMIDT, John FOX, and Liana GRANCEA, 2006, Nationalist Politics and Everyday Ethnicity in a Transylvanian Town. Princeton, Princeton University Press. 
BUNTEN, Alexis C., 2008, "Sharing culture or selling out? Developing the commodified persona in the heritage industry", American Ethnologist, 35 (3): 380-395.

BUZALKA, Juraj, 2007, Nation and Religion: The Politics of Commemoration in South-East Poland. Münster, Lit Verlag.

— 2008, "Europeanization and post-peasant populism in Eastern Europe", Europe-Asia Studies, 60 (5): 757-771.

CARRIER, James, and Josiah McC. HEYMAN, 1997, "Consumption and political economy", Journal of the Royal Anthropological Institute, 3 (2): 355-373.

CASH, Jennifer R., 2007, “Origins, memory, and identity: 'villages' and the politics of nationalism in the Republic of Moldova”, East European Politics and Societies, 21 (4): 588-610.

DUNN, Elisabeth, 2004, Privatizing Poland: Baby Food, Big Business, and the Remaking of Labor. Ithaca, Cornell University Press.

FRIEDMAN, Jonathan, 1994, Cultural Identity and Global Process. Thousand Oaks, Sage Publications.

GLICK SCHILLER, Nina, Ayse CAGLAR, and Thaddeus C. GULDBRANDSEN, 2006, "Beyond the ethnic lens: locality, globality, and born-again incorporation", American Ethnologist, 33 (4): 612-633.

Gross, Jan. T., 2001, Neighbors: The Destruction of the Jewish Community in Jedwabne, Poland. Princeton, Princeton University Press.

GUNERATNE, Arjun, 2001, “Shaping the tourist's gaze: representing ethnic difference in a Nepali village”, Journal of the Royal Anthropological Institute, 7 (3): 527-543.

HAASE, Annegret, 2002, Südostpolen zwishen Umbruch und Neuorientierung: Spezifika, Perspektiven und Risiken der Gesellschaftlichen Entwicklung nach 1990. Leipzig, Institut für Landerkunde.

HALE, Amy, 2001, "Representing the Cornish: contesting heritage interpretation in Cornwall", Tourist Studies, 1 (2): 185-196.

HANN, Chris, 1998a, "Postsocialist nationalism: rediscovering the past in Southeast Poland”, Slavic Review, 57 (4): 840-863.

— 1998 b, "Religion, trade and trust in South-East Poland", Religion, State and Society, 26 (3-4): 235-249.

HIWASAKI, Lisa, 2000, "Ethnic tourism in Hokkaido and the shaping of Ainn identity", Pacific Affairs, 73 (3): 393-412.

KANOVSKÝ, Martin, 2007, "Essentialism and folksociology: ethnicity again”, Journal of Cognition and Culture, 7: 241-281.

MiTCHell, Jon, 2002, Ambivalent Europeans: Rituals, Memory and the Public Sphere in Malta. London, Routledge.

NEVELING, Patrick, and Carsten WERGIN, 2009, "Projects of scale-making: new perspectives for the anthropology of tourism", this volume.

POTRATA, Barbara, 2004, "New age, socialism and other millenarianisms: affirming and struggling with (post)socialism”, Religion, State and Society, 32 (4): 365-379.

PRATT, Jeff, 2007, "Food values: the local and the authentic", Critique of Anthropology, 27 (3): 285-300.

SHORE, Chris, 1993, “Inventing the 'people's Europe': critical approaches to European Community “cultural policy”, Man, 28: 779-800.

—, 2000, Building Europe: The Cultural Politics of European Integration. London, Routledge. 
SIMONI, Valerio, 2009, "Scaling cigars in the Cuban tourism economy", this volume.

SMITH, Valene (ed.), 1978, Hosts and Guests: The Anthropology of Tourism. Philadelphia, University of Pennsylvania Press.

STEWART, Michael, 2003, "The Hungarian status law: a new European form of transnational politics?" Diaspora, 12 (1): 67-102.

STRONZA, Amanda, 2001, "Anthropology of tourism: forging new ground for ecotourism and other alternatives", Annual Review of Anthropology, 30: 261-283.

TSING, Anna, 2000, “The global situation”, Current Anthropology, 15 (3): 327-360.

UITERMARK, Justus, 2002, "Re-scaling, 'scale fragmentation' and the regulation of antagonistic relationships", Progress in Human Geography, 26 (6): 743-765.

ULIN, Robert, 1995, "Invention and representation as cultural capital: Southwest French winegrowing history", American Anthropologist, 97 (3): 519-527.

VAN DEN BERGHE, Pierre, 1994, The Quest for the Other: Ethnic Tourism in San Cristóbal, Mexico. Seattle, University of Washington Press.

Escala e etnicidade no Sudeste da Polónia: turismo na periferia europeia - Juraj Buzalka • Comenius University, Eslováquia • jurajkob@yahoo.com

Este artigo aborda a encenação da etnicidade ucraniana durante as celebrações da Noite de Kupaly, um ritual comunitário que é realizado anualmente no Sudeste da Polónia. A argumentação parte de uma análise da mudança nas políticas nacionais polacas após o socialismo de Estado e sublinha a influência crescente das políticas da União Europeia (UE) na representação pública da etnicidade. Tais políticas fizeram com que o âmbito da etnicidade deixasse de ser o da prática quotidiana, ou mesmo o de uma arena de tensões políticas, tornando-se uma forma de identificação institucionalizada e dominada pelas políticas preconizadas. Na região de Przemý́l, cenário dos acontecimentos aqui analisados, o turismo é um outro factor-chave a favorecer a influência das forças de mercado em projectos relacionados com a preservação do património, o multiculturalismo e a promoção de particularidades étnicas. A análise aqui desenvolvida acerca do modo como estes factores prejudicaram a região demonstra a emergência de um projecto multicultural que tem efeitos ambivalentes, mais do que unificadores. $\mathrm{O}$ artigo explora a forma como a minoria ucraniana em Przemyśl é afectada por processos mais vastos de reconfiguração da escala relacionados com políticas étnicas, sejam elas nacionais, regionais ou europeias, tornando-se assim um grupo mercantilizável e que é valorizado pela UE, pelo Estado, pelos turistas e residentes locais devido à sua cultura distintiva. Demonstra-se assim a ambivalência das relações entre prática ritual, representações públicas da autenticidade, etnoturismo e mudança social sob a influência das políticas e discursos da UE.

PAlaVRAS-ChaVE: etnicidade, periferia europeia, escala, Sudeste da Polónia, turismo. 